Editorial

\title{
Introduction to the Special Issue "Talking about Roma: Implications for Social Inclusion"
}

\author{
Eben Friedman \\ Independent Consultant and Senior Non-resident Research Associate, European Centre for Minority Issues, \\ 24939 Flensburg, Germany; E-Mail: friedmaneben@yahoo.de
}

Submitted: 18 September 2015 | Published: 29 September 2015

\begin{abstract}
By the last decade of the twentieth century, official discourse calling for the elimination of Roma had been largely replaced by approaches aimed at inclusion. Contemporary approaches of this kind can be roughly divided into those which emphasize human rights as a basis for measures to improve the Roma's situation and those rooted in the proposition that improvements in the situation of Roma can be expected to provide economic benefits for the general populations of the countries in which Roma live. The contributions to this special issue critically examine public discourses from throughout Europe which are ostensibly aimed at promoting the social inclusion of Roma. While the fact that the discourses treated fit broadly within human rights and/or economic paradigms allows the articles to speak to one another in various ways, the articles also exhibit a wide range of variation in approach as well as geographical focus. Whereas the first four articles deal directly with issues of definition in relation to Roma, a second group of contributions compares developments across multiple countries or institutions. The last four articles each treat a single country, with the final article narrowing the focus further to a single city.
\end{abstract}

\section{Keywords}

assimilation; economics; genocide; human rights; inclusion; Gypsies; Roma

\section{Issue}

This editorial is part of the special issue "Talking about Roma: Implications for Social Inclusion", edited by Dr. Eben Friedman (Independent Consultant and Senior Non-resident Research Associate, European Centre for Minority Issues, Germany).

(C) 2015 by the author; licensee Cogitatio (Lisbon, Portugal). This article is licensed under a Creative Commons Attribution 4.0 International License (CC BY).

Since Roma first arrived in Europe, policies targeting them have varied both in ultimate aim and in proposed means. In the absence of a consistent direction in official approaches to Roma, from the sixteenth through the late twentieth century Roma in Europe were subject at various times and places not only to policies ranging from assimilation through enslavement to physical extermination, but sometimes also to official approaches recognizing Roma as a legitimate minority with a set of rights to be protected (see Friedman, 2014).

By the last decade of the twentieth century, official discourse calling for the elimination of Roma-whether through mass killing or by abolishing cultural distinctions-had largely given way to approaches explicitly aimed at inclusion. Whereas documents on Roma published in the 1990s by intergovernmental organizations active in Europe tended to emphasize human rights as a basis for calls for measures to improve the Roma's situation, ${ }^{1}$ since the first several years of the current millennium similar calls have been increasingly rooted in the proposition that improvements in the situation of Roma can be expected to provide economic benefits for the general populations of the countries in which Roma live. ${ }^{2}$

\footnotetext{
${ }^{1}$ See, for example, UN Commission on Human Rights (1992); Parliamentary Assembly (1993); European Commission against Racism and Intolerance (1998); UN Committee on the Elimination of Racial Discrimination (2000).

2 See Ringold, Orenstein and Wilkens (2003); de Laat et al. (2010); European Commission (2010, 2011); Parliamentary Assembly (2013).
} 
Each type of approach has its own dangers for social inclusion. On the one hand, the ostensibly hermetic nature of human rights appears to drive some opponents of rights-based policies targeting Roma to call into question Roma's very humanity (see Spiegel Online, 2013), such that the continued deployment of human rights discourse as used to date in relation to Roma risks deepening divisions between Roma and nonRoma (Krastev, 2011; see also aktuálne.sk, 2012). On the other hand, economic arguments for improving the situation of Roma introduce an element of contingency which opens the door also to similarly grounded arguments against improving the situation of Roma and ultimately even to arguments for killing them. ${ }^{3}$

Human rights and economic discourses are sometimes deployed together in attempts to build support for measures to improve the situation of Roma, ${ }^{4}$ but the coexistence of these two types of ostensibly more inclusive approaches is not necessarily an easy one. Simply adding economic considerations to considerations of human rights does not address the ongoing backlash against talk about Roma in terms of human rights. Further, combining human rights arguments with economic ones does not provide explicit guidance on how to adjudicate between the two in case of conflict.

The contributions to this special issue critically examine public discourses from throughout Europe which are ostensibly aimed at promoting the social inclusion of Roma. While the fact that the discourses treated fit broadly within the human rights and/or economic paradigms described above allows the articles to speak to one another in various ways, the articles also exhibit a wide range of variation in approach as well as geographical focus. Whereas the first four articles deal directly with issues of definition in relation to Roma, a second group of contributions compares developments across multiple countries or institutions. The last four articles each treat a single country, with the final article in the special issue narrowing the focus further to a single city.

The first contribution to this special issue is Mihai Surdu and Martin Kovats's examination of practices behind the construction of Roma as an object to be studied and targeted with policy. Tracing links between scholarship on Gypsies in past centuries and presentday research on Roma, the authors point to a selfsustaining cycle of knowledge production, identification of problems, and policy initiatives which effectively reinforces divisions between Roma and non-Roma.

Skepticism about the existence of fundamental dif-

\footnotetext{
3 Krausnick (1995, pp. 173-174) provides details of per capita calculations generated by the SS Central Office of Economic Administration (Wirtschaftverwaltungshauptamt) of the economic benefits of working prisoners to death.

${ }^{4}$ See European Commission (2010, 2011, 2012); European Union Special Representative/EU Office in Kosovo (2013).
}

ferences between current political discourses on the social inclusion of Roma and policies enacted under previous regimes is equally apparent in the contribution by Elena Marushiakova and Veselin Popov. In addition to observing commonalities between EU policy for Roma inclusion on the one hand and the policies of Communist regimes and the Austro-Hungarian Empire on the other, the authors note similarities in the ways in which successive regimes portray the policies of their predecessors. Marushiakova and Popov further characterize targeted policies for the inclusion of Roma as a Catch 22 insofar as they ultimately reinforce the vicious circles which they are introduced to break.

András Pap draws on an analysis of recent legislative developments in Hungary to offer a broad assessment of the relationship between terminology and policy design. More specifically, the article focuses on how inconsistent classification of Roma as an ethnic, racial, or national minority stands in a relationship of mutual reinforcement with inconsistent policy making.

Issues of definition are prominent also in Mary Christianakis's contribution to this special issue. Making use of critical discourse analysis and systemic functional grammar analysis, Christianakis examines the victimization and vilification of Romani children in public discourses on education, human rights, poverty, child rearing, and child labor. The result, in Christianakis's account, is the depiction of Roma as incapable of experiencing a healthy childhood in the absence of interventions by non-Roma.

If portrayals of the past constitute a peripheral feature of Marushiakova and Popov's analysis, they are central to the contribution by Ljiljana Radonić. Case studies on three post-Communist memorial museums provide material for an examination of representations of Roma as victims of genocide during the Second World War. The findings of this examination point to a tension between recognition of genocide against Roma on the one hand and stereotyping and de-personalization on the other.

Joanna Kostka offers a critical look at discourses on Roma exclusion adopted in the framework of EU cohesion policy. Taking such policy as a broad category of proposed solutions to the problems faced by Roma, Kostka explores the representation of problems implicit or explicit in the formulation of Roma inclusion projects supported by EU Structural Funds in Andalusia and Eastern Slovakia, elaborating links between domestic discourses and the scope and quality of such projects.

Characterizing Roma's persistent exclusion despite the expansion of inclusion projects for Roma as a paradox, Chloë Delcour and Lesley Hustinx look for limiting factors within inclusionary discourse. Analyzing reports on human rights violations issued by the Commissioner for Human Rights of the Council of Europe, the European Court of Human Rights, and the European Roma 
Rights Centre as transnational judicial, political, and civil society actors (respectively), the authors find on the one hand a common tendency to frame violations in terms of discrimination but on the other hand differences in prescriptions which undermine the effectiveness of the shared broader discursive frame.

Helen O'Nions offers a legal perspective on the education of Roma as a key indicator of social inclusion. In so doing, she examines the evolution of a social inclusion policy frame in the Decade of Roma Inclusion and follows it into more recent EU policy on Roma. Additionally, she traces a gradual shift in relevant judgements of the European Court of Human Rights from cautious endorsement of integrated education to implicit calls for corrective measures to address disparities in access to and completion of education resulting from discrimination. Despite these developments, however, O'Nions observes that progress toward integrated education has been negligible, attributing this tendency to entrenched social norms reflected in unambitious state policies under the EU Framework for National Roma Integration Strategies.

Education features centrally also in the case study by Ada Ingrid Engebrigtsen, which explores the reasons behind the lack of success of Norwegian government policies implemented over the last 50 years for the purpose of educating Roma. Among the main reasons for this, according to Engebrigtsen, are widespread and superficial understandings of minority culture in general and Romani culture in particular ranging from a combination of art, costume, language, and music to a monolithic expression of a collective will inimical to individual agency and development. Consistent with these understandings, educational models aimed at Roma in Norway have been perceived as alien, bringing covert resistance despite overt consent.

Norma Montesino and Ida Ohlsson Al Fakir examine inclusion policies targeting Roma in Sweden in the period 1950-1970, attending in particular to the uncritical assumptions behind those policies. Montesino and Al Fakir's analysis shows how the classification of Romani adults and children as disabled in different contexts has grounded measures and practices explained in terms of social inclusion but which have effectively reinforced Roma's marginalization.

Reflecting on obstacles to the social inclusion of Roma in Serbia, Jelena Vidojević and Natalija Perišić explore representations of multiple deprivation in public policies and media reports, also conducting interviews and discussions with interlocutors in the social welfare sector. Their findings point to the mutual reinforcement of discourses on Roma across sectors and to a joint contribution to continued exclusion by promoting stereotypes of Roma as fundamentally different from and less civilized than non-Roma.

The final article of this special issue is Elias Hemelsoet and Pauwel van Pelt's case study of Roma in the city of Ghent (Belgium). In the article, the authors examine the fit between official discourses on social inclusion and the experiences and self-perceptions of Romani immigrants from Central and Eastern Europe. This examination in turn forms the basis for conclusions about the potential for the objects of policy to play a role in informing and shaping the policies that affect them.

The special issue also includes two book reviews. The first of these is Victor A. Friedman's review of the book I Met Lucky People: The Story of the Romani Gypsies. The author of that book, Yaron Matras, provides the second review, the object of which is Mihai Surdu's Expert Frames: Scientific and Policy Practices of Roma Classification.

\section{Conflict of Interests}

The author declares no conflict of interests.

\section{References}

aktuálne.sk. (2012). Fico: Bez ústupkov v l'udských právach rómsky problém nevyriešime [Fico: We Won't Solve the Romani Problem without Compromises in Human Rights]. Retrieved from http:// aktualne.atlas.sk/fico-bez-ustupkov-v-ludskych-prav ach-romsky-problem-nevyriesime/slovensko/politika

de Laat, J., Bodewig, C., Arnhold, N., Linden, T., Dulitzky, D., Kosko, S., \& Torrachi, F. (2010). Roma inclusion: An economic opportunity for Europe. Washington, DC: The World Bank.

European Commission. (2010). Communication from the Commission to the Council, the European Parliament, the European Economic and Social Committee and the Committee of the Regions: The social and economic integration of the Roma in Europe (COM/2010/0133 final). Brussels: Commission of the European Communities.

European Commission. (2011). An EU framework for national Roma integration strategies up to 2020. Communication from the Commission to the European Parliament, the Council, the European Economic and Social Committee and the Committee of the Regions COM (2011) 173 final. Brussels: Commission of the European Communities.

European Commission. (2012). National Roma integration strategies: A first step in the implementation of the EU framework. Communication from the Commission to the European Parliament, the Council, the European Economic and Social Committee and the Committee of the Regions COM (2012) 226 final. Brussels: Commission of the European Communities.

European Commission against Racism and Intolerance. (1998). ECRI general policy recommendation No. 3 on combating racism and intolerance against Roma/Gypsies. Strasbourg: Council of Europe. 
European Union Special Representative/EU Office in Kosovo. (2013). To engage more deeply for Kosovo Roma, Ashkali and Egyptian communities. Pristina: European Union Special Representative/EU Office in Kosovo.

Friedman, E. (2014). The situation of Roma between human rights and economics. Flensburg: European Centre for Minority Issues.

Krastev, I. (2011). Roma and the politics of demographic imagination. In M. Flašíková-Beňová, H. Swoboda, \& J. M. Wiersma (Eds.), Roma: A European minority. The challenge of diversity (pp. 45-53). Brussels: European Parliament.

Krausnick, M. (1995). Wo sind sie hingekommen? Der unterschlagene Völkermord an den Sinti und Roma [Where did they come from? The unrevealed geno- cide on the Sinti and Roma]. Gerlingen: Bleicher.

Parliamentary Assembly. (1993). Recommendation 1203 (1993) on Gypsies in Europe. Strasbourg: Council of Europe.

Parliamentary Assembly. (2013). Recommendation 1927 (2013): Ending discrimination against Roma children. Strasbourg: Council of Europe.

Ringold, D., Orenstein, M. A., \& Wilkens, E. (2003). Ro$m a$ in an expanding Europe: Breaking the poverty cycle. Washington, DC: World Bank.

UN Commission on Human Rights. (1992). Protection of Roma (gypsies). Geneva: United Nations.

UN Committee on the Elimination of Racial Discrimination (CERD). (2000). CERD general recommendation XXVII on discrimination against Roma. Geneva: United Nations.

\section{About the Author}

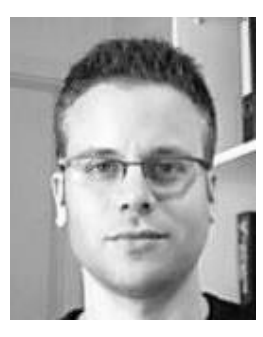

\section{Dr. Eben Friedman}

Eben Friedman holds a Ph.D. in political science from the University of California, San Diego. The title of his doctoral dissertation was "Explaining the Political Integration of Minorities: Roms as a Hard Case." Since working for the European Centre for Minority Issues (ECMI) from 2002 to 2007 and for the Roma Education Fund (2007-2012), Friedman has undertaken advisory, analytical, and research assignments as an independent consultant. Additionally, he is affiliated with ECMI as a Senior Nonresident Research Associate. Friedman's publications have focused largely on ethnopolitics in Macedonia and on Roma. 